\title{
DUKUNGAN KELUARGA TERHADAP KEPATUHAN MINUM OBAT PADA PASIEN DM TIPE II
}

\author{
Family Support Towards Drug Adherence In Type II Diabetes Mellitus
}

\section{Reny Sulistyowati I ${ }^{\text {* }}$ \\ Agnes Dewi Astuti $2^{2}$}

*Palangka Raya, Kalimantan Tengah, Indonesia

2 Palangka Raya, Kalimantan Tengah, Indonesia

*email:

reny.sulistyowati7076@gmail.com

Kata Kunci:

DM Tipe II

Dukungan Keluarga

Kepatuhan Minum Obat

\section{Keywords:}

Type II DM

Family Support

Medication adherence

\begin{abstract}
Abstrak
Tingkat kepatuhan biasanya menurun pada pasien dengan kondisi kronis dibandingkan dengan kondisi akut; ini terkait dengan sifat jangka panjang dari penyakit kronis karena penurunan kepatuhan yang paling cepat setelah 6 bulan pertama terapi. Penurunan kepatuhan tersebut tidak hanya menghasilkan hasil kesehatan yang buruk tetapi juga berdampak signifikan pada biaya kesehatan. Tujuan penelitian ini adalah untuk mengetahui dukungan keluarga terhadap kepatuhan minum obat pada pasien DM tipe 2. Penelitian ini menggunakan desain descriptive correlational dengan menggunakan pendekatan cross sectional study pada 100 orang responden. Data demografi pasien dan dukungan keluarga di peroleh dengan menggunakan kuesioner sedangkan tingkat kepatuhan menggunakan Morisky Medication Adherence Scales. Hasil menunjukkan ada hubungan dukungan keluarga dengan kepatuhan minum obat pada pada pasien DM tipe 2 yang dilihat dari 4 dimensi yaitu dukungan penghargaan, dukungan emosional, dukungan informasi dan dukungan instrumental. Kesimpulan: Adanya dukungan dari keluarga dapat meningkatkan kepatuhan minum obat pada pasien DM tipe 2.
\end{abstract}

\begin{abstract}
Level of adherence usually decreases in patients with chronic conditions compared to acute conditions; this is related to the long-term nature of chronic disease due to the most rapid decrease in adherence after the first 6 months of therapy. The decline in compliance not only resulted in poor health outcomes but also had a significant impact on health costs. The purpose of this study was to determine family support for medication adherence in type 2 DM patients. This study used descriptive correlational using a cross-sectional study approach on 100 respondents. Patient demographic data and family support were obtained using a questionnaire while the level of compliance used Morisky Medication Adherence Scales. The results show that there is a relationship between family support and medication adherence in patients with type 2 diabetes, which is viewed from 4 dimensions: appreciation support, emotional support, information support, and instrumental support. Support from family can improve medication adherence in type $2 \mathrm{DM}$ patients.
\end{abstract}

(C) year The Authors. Published by Institute for Research and Community Services Universitas Muhammadiyah Palangkaraya. This is Open Access article under the CC-BY-SA License (http://creativecommons.org/licenses/bysa/4.0/). DOI: https://doi.org//0.33084/jsm.vxix.xxx.

\section{PENDAHULUAN}

Diabetes Melitus merupakan keadaan hiperglikemia kronis yang disebabkan oleh faktor lingkungan dan keturunan secara bersama-sama dan mempunyai karakteristik hiperglikemia kronis tidak dapat disembuhkan tetapi dapat dikontrol (WHO, 2008). Diabetes Melitus menempati urutan ke-3 di Indonesia sebagai penyakit penyebab kematian terbanyak. Obatobatan dan perubahan gaya hidup untuk mengontrol diabetes tipe 2 dan kondisi lain yang berhubungan hanya dapat efektif melalui kepatuhan terhadap regimen yang diresepkan. Angka kepatuhan biasanya turun pada pasien dengan kondisi-kondisi kronis daripada pada kondisi akut; hal ini berhubungan dengan sifat jangka panjang dari kondisi kronis karena penurunan terhadap kepatuhan lebih sering setelah 6 bulan terapi. seperti penurunan kepatuhan tidak hanya akibat minimnya fasilitas kesehatan namun juga memiliki dampak signifikan pada biaya pengobatan. Sehingga, keseluruhan manajemen diabetes tipe 2 harus membahas kepatuhan sebagaimana halnya dengan pengobatan yang 
tepat/harus membahas kepatuhan serta obat yang sesuai (Pe'rez, A' Ivarez, dkk, 20I3). Tujuan penelitian ini adalah untuk mengetahui peran keluarga dalam mendukung kepatuhan minum obat pada pasien DM tipe 2.

Dukungan keluarga memiliki peran penting terhadap kepatuhan minum obat pada pasien DM tipe 2. Ada 4 dimensi dukungan keluarga yaitu dimensi emosional/empati, dimensi penghargaan, dimensi instrumental dan dimensi informasi. I) Dimensi emosional/empati, melibatkan ekspresi, rasa empati dan perhatian terhadap seseorang sehingga membuatnya merasa lebih baik, memperoleh kembali keyakinannya, merasa dimiliki dan dicintai pada saat stres. DM dapat menimbulkan gangguan psikologis bagi penderitanya. Hal ini disebabkan karena penyakit DM tidak dapat disembuhkan dan mempunyai risiko untuk mengalami komplikasi. Kondisi seperti ini dapat mempengaruhi seseorang dalam mengendalikan emosi. Bila muncul masalah depresi pada pasien bantuan medis mungkin diperlukan namun yang tidak kalah penting adanya dukungan keluarga yang akan mendorong pasien untuk dapat mengendalikan emosi dan waspada terhadap hal yang mungkin terjadi; 2) Dimensi penghargaan, dimensi ini terjadi melalui ekspresi berupa sambutan yang positif dengan orang-orang disekitarnya, dorongan atau pernyataan setuju terhadap ide-ide atau perasaan individu. Bentuk dukungan penghargaan ini muncul dari pengakuan dan penghargaan terhadap kemampuan dan prestasi yang dimiliki seseorang; 3) Dimensi instrumental, bersifat nyata, dimana dukungan ini berupa bantuan langsung, contohnya seperti seseorang yang memberikan atau meminjamkan uang. Dapat juga berupa bantuan mengerjakan tugas tertentu pada saat mengalami stres. Dukungan instrumental keluarga merupakan suatu dukungan atau bantuan penuh keluarga dalam bentuk memberikan bantuan tenaga, dana maupun menyediakan waktu untuk melayani dan mendengarkan keluarga yang sakit dalam menyampaikan perasaannya (Bomar, 2004); 4) Dimensi informasi, berupa pemberian saran atau percakapan atau umpan balik tentang bagaimana seseorang melakukan sesuatu, misalnya ketika seseorang mengalami kesulitan dalam pengambilan keputusan, dia akan menerima saran dan umpan balik tentang ide-ide dari keluarganya. Dimensi ini menyatakan dukungan keluarga yang diberikan bisa membantu pasien dalam mengambil keputusan dan menolong pasien dari hari ke hari dalam manajemen penyakitnya.

\section{METODOLOGI}

Penelitian ini menggunakan desain descriptive correlational dengan menggunakan pendekatan cross sectional study. Penelitian ini diawali dengan melihat gambaran dari masing-masing variabel meliputi variabel dependen yaitu kepatuhan minum obat serta variabel independen yaitu dukungan keluarga. Deskripsi korelasional pada penelitian ini yaitu dengan menggambarkan hubungan dukungan keluarga dengan kepatuhan minum obat. Jumlah responden sebanyak 100 orang. Penelitian dilakukan di wilayah kerja Puskesmas Jekan Raya. Kriteria inklusi penelitian adalah responden yang mengidap Diabetes mellitus tipe 2 dengan usia berada pada rentang 36 - 55 tahun, tinggal bersama keluarga dan mendapat terapi obat hipoglikemik oral. Instrumen yang digunakan dengan menggunakan kuesioner untuk mengambil data demografi, kuesiner dukungan keluarga dan untuk tingkat kepatuhan obat dengan menggunakan kuesioner Morisky Medication Adherence Scales: MMAS-8.

Kuesioner yang digunakan untuk memperoleh data demografi, kuesioner variabel dukungan keluarga menggunakan 38 pertanyaan awal dari kuesioner. Untuk pernyataan positif, setiap pernyataan memiliki empat pilihan kriteria yaitu $4=$ selalu, $3=$ sering , 2 = kadangkadang dan $\mathrm{I}=$ tidak pernah. Untuk pernyataan negatif setiap pernyataan memiliki empat pilihan kriteria yaitu 4 = tidak pernah, 3 = kadang-kadang, $2=$ sering $\operatorname{dan} \mathrm{I}=$ selalu. Responden memberikan jawaban dengan cara 
memberi tanda check list $(\sqrt{ })$ pada pilihan jawaban yang telah disediakan. Hasil ukur untuk dukungan keluarga dikategorikan $\mathrm{I}=$ baik, dan, $0=$ kurang baik. Untuk pengukuran tingkat kepatuhan minum obat Peneliti menggunakan kuesioner Morisky Medication Adherence Scales: MMAS-8. Peneliti mengkategorikan tingkat kepatuhan responden sebagai patuh dan tidak patuh.

Analisis bivariat dalam penelitian ini bertujuan untuk mengetahui apakah ada hubungan yang bermakna antara dua variabel yaitu independen (kepatuhan minum obat) dan variabel dependen (dukungan keluarga). Jenis data dalam penelitian ini adalah berbentuk kategorik dengan skala ordinal sehingga uji coba statistik yang digunakan yaitu uji Chi Square (Kai Kuadrat) (Dharma, 20II). Uji Chi Square digunakan apabila variabel independent dan variabel dependent merupakan data kategorik. Tingkat kemaknaan (nilai alpha) yang digunakan dalam uji ini adalah sebesar 0,05 dengan $\mathrm{Cl}$ (95\%). Jika ingin mengetahui keeratan hubungan, dapat diketahui dari nilai Odd Ration (OR). Dari hasil uji didapat nilai probabilitas, kemudian membandingkan nilai $\mathrm{P}$ value yang didapat dengan nilai alpha=0,05. Apabila $p$ value $<0,05$ maka ada hubungan antar variabel (Hastono, 2007).

Bila hasil bivariat menghasilkan pvalue $<0,25$, maka variabel tersebut langsung masuk tahap multivariat. Untuk variabel independen dengan hasil analisis bivariatnya menghasilkan pvalue $>0,25$ namun secara substansi penting, maka variabel tersebut dapat dimasukkan dalam model multivariat (Hastono \& Luknis, 2008). Mutivariate analysis adalah analisis yang melibatkan banyak variable atau variable ganda. Analisis multivariat dilakukan dengan tujuan untuk melihat hubungan beberapa variabel (lebih dari satu) independen dengan satu atau beberapa variabel dependen (umumnya satu variabel dependen). Dalam analisa multivariat akan diketahui variabel independen mana yang paling besar pengaruhnya terhadap variabel dependen (Hastono, 2007 dalam Lestari, 2009).

\section{HASIL DAN PEMBAHASAN}

Jumlah responden yang mengalami Diabetes mellitus sebanyak 100 orang dengan rentang usia 36 sampai 55 tahun. Tabel. I menunjukkan Karakteristik demografi.

Tabel I. Karakteristik Responden

\begin{tabular}{lc}
\hline \multicolumn{1}{c}{ Variabel } & Persen \\
\hline Usia dewasa awal (36-45 tahun) & 45 \\
Usia dewasa akhir (46-55 tahun) & 55 \\
Pria & 73 \\
Wanita & 27 \\
Pendidikan rendah & 63 \\
Pendidikan tinggi & 37 \\
Lama Menderita DM > 6 bulan & 67 \\
Lama menderita DM < 6 bulan & 33 \\
Dukungan keluarga kurang baik & 48 \\
Dukungan keluarga baik & 52 \\
Dukungan penghargaan keluarga baik & 36 \\
Dukungan emosional keluarga baik & 29 \\
Dukungan instrumental keluarga baik & 44 \\
Dukungan informasi keluarga baik & 50 \\
\hline
\end{tabular}

Tujuan penelitian ini adalah untuk mengetahui peran keluarga dalam mendukung kepatuhan minum obat pada pasien DM tipe II. Usia harapan hidup di Indonesia tahun 2016-2020 adalah sebesar 70,7 tahun. DM menempati urutan penyakit ke-3 dari 10 penyakit terbanyak penyebab kematian pada pasien DM tahun 2016 di Indonesia. Dari hasil penelitian yang didapatkan usia lebih dari 45 tahun ditemukan sebanyak 55 orang dibandingkan usia dewasa akhir antara usia $36-45$ tahun sebanyak 45 orang. Responden perempuan berpeluang I,694 kali untuk memiliki kepatuhan minum obat yang tinggi dibandingkan dengan yang responden laki-laki. Nilai OR I,694 berarti kemungkinan responden yang perempuan akan memiliki kepatuhan dalam minum obat sebesar $62,8 \%$ dari pada responden laki-laki [P = OR/(I+OR)].

Hasil analisis hubungan pendidikan dengan kepatuhan minum obat diperoleh bahwa sebanyak 24 responden $(64,9 \%)$ yang berpendidikan tinggi memiliki kepatuhan 
yang tinggi. Sedangkan 30 responden (47,6\%) berpendidikan rendah memiliki kepatuhan minum obat yang tinggi. Dari hasil analisis diperoleh pula nilai $\mathrm{OR}=$ 2,03I, artinya responden yang berpendidikan tinggi berpeluang 2,03I kali memiliki kepatuhan minum obat yang tinggi dibandingkan dengan yang berpendidikan rendah. Nilai OR 2,03 I berarti kemungkinan pendidikan tinggi akan membuat kepatuhan responden dalam minum obat sebesar $67,01 \%$ dari pada responden berpendidikan rendah $[\mathrm{P}=\mathrm{OR} /(\mathrm{I}+\mathrm{OR})]$.

Ada hubungan yang signifikan antara lama menderita DM dengan kepatuhan minum obat. Dari hasil analisis diperoleh pula nilai $O R=2,67 \mathrm{I}$, artinya responden yang menderita $D M<6$ bulan berpeluang 2,67I kali memiliki kepatuhan minum obat yang tinggi dibandingkan dengan yang menderita DM >6 bulan. WHO menyatakan bahwa kepatuhan terhadap terapi jangka panjang untuk penyakit kronis di negara berkembang rata-rata hanya sekitar 50\% (Pe'rez, A' Ivarez, 20I3). Angka kepatuhan biasanya turun pada pasien dengan kondisi-kondisi kronis daripada pada kondisi akut; hal ini berhubungan dengan sifat jangka panjang dari kondisi kronis karena penurunan terhadap kepatuhan lebih sering setelah 6 bulan terapi (8). seperti penurunan kepatuhan tidak hanya akibat minimnya fasilitas kesehatan namun juga memiliki dampak signifikan pada biaya pengobatan (7).

Hubungan dukungan penghargaan keluarga dengan kepatuhan minum obat diperoleh bahwa sebanyak 22 responden (6I,I\%) yang mendapatkan dukungan penghargaan keluarga yang baik memiliki kepatuhan yang tinggi, sedangkan 32 responden (50\%) yang mendapatkan dukungan penghargaan keluarga yang kurang baik memiliki kepatuhan minum obat yang tinggi. Hasil uji hipotesis Chi Square dua sisi (2-sided) diperoleh nilai $p=0,389$. Maka dapat disimpulkan tidak ada hubungan yang signifikan antara dukungan penghargaan keluarga dengan kepatuhan minum obat. Dari hasil analisis diperoleh pula nilai $O R=1,57 \mathrm{I}$, artinya responden yang memiliki dukungan penghargaan keluarga yang baik berpeluang I,57 I kali untuk memiliki kepatuhan minum obat yang tinggi dibandingkan dengan responden yang kurang mendapatkan dukungan penghargaan dari keluarga. Nilai OR I,57I berarti kemungkinan responden yang mendapatkan dukungan penghargaan keluarga yang baik akan memiliki kepatuhan dalam minum obat sebesar 6I,1\% dari pada responden yang kurang mendapatkan dukungan penghargaan keluarga $[\mathrm{P}=\mathrm{OR} /(\mathrm{I}+\mathrm{OR})]$.

Hasil penelitian ini sejalan dengan Bomar (2004) yang menyatakan dukungan penghargaan merupakan suatu dukungan atau bantuan dari keluarga dalam bentuk memberikan umpan balik dan penghargaan dengan menunjukkan respon positif yaitu dorongan atau persetujuan terhadap gagasan/ide atau perasaan seseorang. Adanya dukungan penilaian yang diberikan keluarga terhadap diabetesi berupa penghargaan, dapat meningkatkan status psikososial, semangat, motivasi dan peningkatan harga diri, karena dianggap masih berguna dan berarti untuk keluarga sehingga diharapkan dapat membentuk perilaku yang sehat pada diabetesidalam upaya meningkatkan status kesehatannya. Sehingga dari analisa peneliti, otomatis jika pasien DM mendapatkan dukungan penghargaan, maka dapat meningkatkan status kesehatannya dengan cara pasien akan lebih semangat dan termotivasi dalam menjalani program pengobatannya, mengingat penyakit DM merupakan penyakit yang tidak dapat disembuhkan namun hanya bisa dikontrol dengan menjalani terapi DM. Dengan demikian kepatuhan untuk minum obat pun akan meningkat.

Hubungan dukungan emosional keluarga dengan kepatuhan minum obat diperoleh bahwa sebanyak 16 responden (55,2\%) yang mendapatkan dukungan emosional keluarga yang baik memiliki kepatuhan yang tinggi. Sedangkan 38 responden (53,5\%) yang kurang mendapatkan dukungan emosional keluarga memiliki kepatuhan minum obat yang tinggi. Hasil uji hipotesis Chi Square dua sisi (2-sided) diperoleh nilai $p=1,000$, lebih besar dari nilai $\alpha=0,05$, sehingga Ho diterima, disimpulkan tidak ada hubungan yang signifikan antara 
dukungan emosional keluarga dengan kepatuhan minum obat. Dari hasil analisis diperoleh pula nilai $O R=1,069$, artinya responden yang memiliki dukungan emosional keluarga yang baik berpeluang I,069 kali untuk memiliki kepatuhan minum obat yang tinggi dibandingkan dengan responden yang kurang baik mendapatkan dukungan emosional dari keluarga. Nilai OR I,57I berarti kemungkinan responden yang mendapatkan dukungan emosional keluarga yang baik akan memiliki kepatuhan minum obat sebesar $61,10 \%$ dari pada responden yang kurang mendapatkan dukungan emosional keluarga [P = $\mathrm{OR} /(\mathrm{I}+\mathrm{OR})]$.

Hasil analisis hubungan dukungan informasi keluarga dengan kepatuhan minum obat diperoleh bahwa sebanyak 45 responden (90\%) mendapatkan dukungan informasi keluarga yang baik memiliki kepatuhan yang tinggi. Sedangkan 9 responden (I8\%) yang kurang baik mendapatkan dukungan informasi keluarga memiliki kepatuhan minum obat yang tinggi. Hasil uji hipotesis Chi Square dua sisi (2-sided) diperoleh nilai $p=0,000$, ada hubungan yang signifikan antara dukungan informasi keluarga yang baik dengan kepatuhan minum obat. Dari hasil analisis diperoleh pula nilai $O R=4 I, 00$, artinya responden yang mendapatkan dukungan informasi keluarga yang baik berpeluang $4 \mathrm{I}$ kali memiliki kepatuhan minum obat yang tinggi dibandingkan dengan yang kurang mendapatkan dukungan informasi keluarga. Nilai OR 4I,00 berarti kemungkinan dukungan informasi keluarga yang baik akan membuat kepatuhan responden dalam minum obat sebesar $97,62 \%$ dari pada responden yang kurang mendapatkan dukungan informasi keluarga [P = OR/(I+OR)].

Hasil analisis hubungan dukungan instrumental keluarga dengan kepatuhan minum obat diperoleh bahwa sebanyak 21 responden $(47,7 \%)$ yang mendapatkan dukungan instrumen keluarga yang baik memiliki kepatuhan yang tinggi, sedangkan 33 responden (58,9\%) yang kurang baik mendapatkan dukungan instrumen keluarga memiliki kepatuhan minum obat yang tinggi. Hasil uji hipotesis Chi Square dua sisi (2-sided) diperoleh nilai $p=0,36 \mathrm{I}$ sehingga tidak ada hubungan yang signifikan antara dukungan instrumen keluarga dengan kepatuhan minum obat. Dari hasil analisis diperoleh pula nilai $O R=0,636$, artinya responden yang memiliki dukungan instrumen keluarga yang baik berpeluang 0,636 kali untuk memiliki kepatuhan minum obat yang tinggi dibandingkan dengan yang responden yang kurang baik mendapatkan dukungan instrumen dari keluarga. Nilai OR 0,636 berarti kemungkinan responden yang mendapatkan dukungan instrumen keluarga yang baik akan memiliki kepatuhan dalam minum obat sebesar $38,87 \%$ dari pada responden yang kurang mendapatkan dukungan instrumen keluarga $[\mathrm{P}=$ OR/(I+OR)]. Setelah dilakukan analisis akhir, maka dapat disimpulkan sebagai berikut: Variabel yang paling besar pengaruhnya terhadap kepatuhan minum obat adalah dukungan informasi keluarga.

Hasil penelitian ini sesuai dengan pernyataan bahwa dukungan instrumental keluarga merupakan suatu dukungan atau bantuan penuh keluarga dalam bentuk memberikan bantuan tenaga, dana maupun menyediakan waktu untuk melayani dan mendengarkan keluarga yang sakit dalam menyampaikan perasaannya (Bomar, 2004). Dukungan instrumental bertujuan untuk mempermudah seseorang dalam melakukan aktifitasnya berkaitan dengan persoalan-persoalan yang dihadapinya atau menolong secara langsung kesulitan yang dihadapi, misalnya dengan menyediakan peralatan lengkap dan memadai bagi pasien, menyediakan obatobatan yang dibutuhkan, dan lain-lain. Dengan adanya dukungan instrumental yang cukup pada pasien DM diharapkan kondisi pasien DM dapat terjaga dan terkontrol dengan baik sehingga dapat meningkatkan status kesehatannya.

\section{KESIMPULAN}

Dari hasil penelitian disarankan bagi Dinas Kesehatan Kota dapat mengembangkan kebijakan pelayanan kesehatan untuk memasukkan kedalam sebuah program di Puskesmas, menggalakkan pentingnya dukungan 
keluarga karena memiliki peran terhadap peningkatan kepatuhan minum obat pada diabetesi. Salah satunya dengan menambah suatu kegiatan rutin di Posyandu yang melibatkan keluarga. Bagi keluarga dan pasien DM dapat meningkatkan peran serta keluarga dalam meningkatkan kualitas hidup pasien DM, salah satunya dengan meningkatkan kepatuhan dalam minum obat DM. Karena salah satu rendahnya motivasi keluarga untuk terlibat dalam penatalaksanaan pasien DM adalah karena faktor ketidak tahuan dari keluarga.

\section{UCAPAN TERIMA KASIH}

Penulis mengucapkan terima kasih kepada Direktur Poltekkes Kemenkes Palangka Raya atas kesempatan yang telah diberikan; Kepala Pusat Penelitian dan Pengabdian Kepada Masyarakat beserta staf, Kepala Puskesmas Jekan Raya beserta staf dan enumerator serta responden penelitian serta seluruh pihak yang telah membantu sehingga penelitian ini dapat terlaksana dengan baik.

\section{REFERENSI}

I. World Health Organization. (20II). World Health Statistic

2. Pe'rez, L.E.G, A'lvarez, M, Dilla, T, dkk. 2013. Adherence to Therapies in Patients with Type 2 Diabetes. Diabetes Therapy 4:175-194.

3. Bomar, P.J. 2004. Promoting Health in Families: Applying Family Research and Theory to Nursing Practice. Philadelphia: WB Saunders Company.

4. Hastono, S.P. 2007. Analasis Data Kesehatan. Jakarta: FKM UI.

5. American Diabetes Association. 2005. Diabetes Care: A Systematic Review of Adherence With Medication For Diabetes by Cramer, J.A.

6. Ariani \& Maulana. 2016. Hubungan Pemberian Informasi Obat Dengan Kepatuhan Minum Obat Antibiotik Pada Pasien Rawat Jalan di Puskesmas Remaja Samarinda.

7. Aryono, S. M. 2008. Pencegahan DM Tipe II, diunduh dari http://www.acarakedokteran.wordpress.com
8. Asti, T.I. 2006. Kepatuhan Pasien: Faktor Penting Dalam Keberhasilan Terapi. Jurnal Badan POM RI Vol. 7.

9. Badan Pusat Statistik. 2014. Jumlah Penduduk Indonesia Berdasarkan Jenis Kelamin, diunduh dari http://www.bps.go.id

I0. Friedman, M. M., Bowden, V.R., \& Jones, E.G. (2003). Family Nursing: Research, Theory, \& Practice. New Jersey: Pearson Education, Inc.

II. Friedman, MM., Bowden, V.R., Jones, E.G. 2010. Buku Ajar Keperawatan Keluarga: Riset, teori dan praktik. Alih bahasa: Achir Yani S.Hamid, dkk.Ed.5. Jakarta: EGC.

12. Kementerian Kesehatan Republik Indonesia. (20II). Pedoman Pengendalian Faktor Risiko Penyakit Jantung dan Pembuluh Darah. Jakarta : Kementerian Kesehatan Republik Indonesia, Direktorat Jenderal PP \& PL, Direktorat Pengendalian Penyakit Tidak Menular.

13. Kristianingrum, Y \& Budiyani, K. 20II. Dukungan Keluarga dan Kepatuhan Minum Obat Pada Orang Dengan Diabetes Melitus,dari http://psychoidea.ump.ac.id/index.php/psikologi/art icle/view/92/69

14. Kuntjoro, Z.R. 2002. Keharmonisan Kehidupan Keluarga Diabetesi, diperoleh dari http://www.epsikologi.com/epsi/lanjutusia_detail.asp?id=1100.

15. Miller, C.A. 2012. Nursing Care of Older Adult: Theory and Practice. Philadelphia: Lippincott Williams \& Wilkins.

16. Morisky DE, Green LW, Levine DM. Concurrent and predictive validity of a self-reported measure of medication adherence. Med Care. 1986;24:6774; Morisky Medication Adherence Scales: MMAS4 and MMAS-8, diunduh dari https://www.mainequalitycounts.org/image_upload 15_Morisky_Medication_Adherence.pdf.

17. Naing, MM., Nanthamongkolchai S., Munsawaengsub C. 2010. Quality of Life of the Elderly People in Einme Township Irrawaddy Division, Myanmar. Asia Journal of Public Health,, I (2), 4-I0.

18. Osterberg L, Blaschke T. Adherence to medication. N EnglJ Med. 2005;353:487-97.

19. Polonsky, W.H. 2000. Understanding and Assessing Diabetes-Specific Quality of Life. Diabetes Spectrum Volume 13 Number, 2000, page $36 . \quad$ Diakses dari http://www.journal.diabetes.org/diabetesspectrum/ $00 \mathrm{vl} 3 \mathrm{nl} / \mathrm{pg} 36 . \mathrm{htm}$

20. Pusat Data dan Informasi Kementerian Kesehatan RI. 20I4. Situasi dan Analisis Diabetes. 
21. Rustika \& Riyadina, W. 2000. Profil penduduk Diabetesi di Indonesia, diunduh dari http://ejournal.litbang.depkes.go.id/index.php/MPK/ article/view/9100.

22. Soegondo, S. 2006. Farmakoterapi Pada Pengendalian Glikemia DM tipe 2. Buku Ajar llmu Penyakit Dalam. Jakarta: Pusat Penerbitan Departemen IImu Penyakit Dalam FKUI.

23. Suyono, J. 2000. Pencegahan Diabetes Melitus: Laporan Kelompok Studi WHO (Prevention of DM). Jakarta: Hipokrates

24. Taylor, S.E. 2006. Health Psychology 6th ed. Singapore: Mc Grow Hill Book Company.

25. Tjokroprawiro, A. 1994. Diabetes Melitus. Jakarta: Gramedia.

26. Wu, S.F.V. 2007. Effectiveness of Self Management for Person With Type 2 Diabetes following The Implementation of A Self-Efficacy Enhanching Intervention Program In Taiwan. Queensland University of Technology.

27. Yenni. 20II. Hubungan Dukungan Keluarga dan Karakteristik Lansia Dengan Kejadian Stroke Pada Lansia Hipertensi Di Wilayah Kerja Puskesmaan Perkotaan Bukit Tinggi. 